\title{
WSPÓLPRACA PARLAMENTÓW NARODOWYCH Z PARLAMENTEM EUROPEJSKIM W ZAKRESIE TWORZENIA PRAWA
}

\section{COOPERATION OF NATIONAL PARLIAMENTS WITH THE EUROPEAN PARLIAMENT IN THE SCOPE OF LAWMAKING}

The article presents relations between parliaments of the European Union Member States (Poland, France, Sweden) and the European Parliament, from the perspective of the few years that had passed since the Treaty of Lisbon went into fore. The aim is to assess effectiveness of the legal norms laid down by the Treaty of Lisbon as regards regulations concerning national parliaments. Different manners of regulating the matter in question by individual states may have an impact on the sphere of trans-institutional activity (number of reasoned opinions, intensity of political dialogue etc.). Moreover, regulating cooperation between the national parliament and the European Parliament by the higher-ranking law may confer special legal value on those prerogatives of the parliament. Acknowledging these differences may initiate further analysis on expanding the EU law as regards national parliaments and their relations with European Parliament.

Słowa kluczowe: Parlament Europejski, parlamenty państw członkowskich, traktat z Lizbony

Key words: European Parliament, parliaments of the EU Member States, Treaty of Lisbon

* Mgr Rafal Czarski, Kancelaria Sejmu, Biuro Spraw Międzynarodowych, rafal.czarski@sejm.gov.pl,https://orcid.org/0000-0002-7321-2405

\section{WSTĘP}

Tedną z relacji instytucjonalnych, które w Unii Europejskiej powodują liczne dyskusje dotyczące pozycji i zakresu zbieżnych — wydawałoby się — ze sobą kompetencji, jest relacja między parlamentami narodowymi a Parlamentem Europejskim [dalej: PE]. Ten system współzależności został określony jako odgrywanie odrębnych, a zarazem komplementarnych ról w realizacji zasadniczego zadania, jakim jest wzmocnienie demokratycznej odpowiedzialności w sprawach Unii Europejskiej ${ }^{1}$. Należy jednak zauważyć znaczne różnice zakresu kompetencji między tymi organami: podstawową funkcją parlamentów państwowych jest ich funkcja prawodawcza, z kolei uprawnienia ustawodawcze PE są znacznie zawężone, gdyż zakładają współpracę na różnych etapach i w ramach istniejących procedur z innymi instytucjami UE. W zależności od procedury legislacyjnej rola PE może dotyczyć współdecydowania (zwykła procedura ustawodawcza) lub jedynie roli konsultacyjnej (specjalne procedury legislacyjne).

${ }^{1}$ Resolution on the relations between the European Parliament and national parliaments, T4-0319/ 1997, 22 II 1997, s. 75, <http://www.europarl.europa.eu/calendar/calendar?APP=PDF\&TYPE=PV2\&FILE= 19970612EN.pdf\&LANGUE=EN>, dostęp 28 VII 2018. 
Przedmiotem niniejszego artykułu jest zaprezentowanie, w szczególności z perspektywy kilku lat od wejścia w życie Traktatu z Lizbony, relacji parlamentów narodowych z PE. Zakres omawianego zagadnienia obejmuje doświadczenia polskiego parlamentu: Sejmu i Senatu, a także dwóch innych parlamentów państw członkowskich Unii: Zgromadzenia Narodowego i Senatu Republiki Francuskiej oraz Riksdagu Królestwa Szwecji. O wyborze zadecydowały następujące czynniki: Republika Francuska - to jedno z państw założycieli UE, Szwecja - to państwo odznaczające się dużą aktywnością w sferze interakcji instytucjonalnej z PE, i Polska - państwo badania. Ukazanie tych trzech perspektyw ma przedstawić obraz doświadczeń i wewnętrznych ram współpracy między parlamentami a instytucjami unijnymi, głównie Parlamentem Europejskim.

Temat współpracy parlamentów narodowych z PE wydaje się szczególnie aktualny w związku z podejmowaniem na różnych forach europejskich dyskusji na temat zwiększenia roli parlamentów narodowych w procesie decyzyjnym Unii Europejskiej. Jeden $\mathrm{z}$ takich głosów w debacie na ten temat zaprezentowano podczas posiedzenia plenarnego Konferencji Komisji do Spraw Unijnych Parlamentów Unii Europejskiej, LIX COSAC 2018, które odbyło się 17-19 czerwca 2018 r. w Sofii. W propozycji francuskiej wskazano na potrzebę rozbudowy uprawnień parlamentów państwowych w zakresie ich aktywności europejskiej dotyczącej sfery gospodarczej — negocjacji umów handlowych ${ }^{2}$. Wśród postulatów o zoptymalizowaniu współpracy parlamentarnej i przyznaniu większej roli parlamentom narodowym pojawiają się liczne opinie dotyczące wprowadzenia zielonych i czerwonych kartek, umożliwiających parlamentom inicjatywę ustawodawczą ${ }^{3}$ lub też możliwość blokowania projektu ustawodawczego. Propozycje te dowodzą tego, jak istotny z punktu widzenia parlamentów narodowych jest udział w procesie decyzyjnym $\mathrm{UE}^{4}$.

W tym opracowaniu zamierzeniem autora jest zaprezentowanie rozwoju relacji między parlamentami Polski, Francji i Szwecji a Parlamentem Europejskim w celu oceny skuteczności norm Traktatu z Lizbony z punktu widzenia uregulowań dotyczących parlamentów narodowych. Odmienne sposoby regulacji przedmiotowej kwestii w porządkach prawnych poszczególnych państw mogą mieć przełożenie na sferę aktywności międzyinstytucjonalnej (liczby zgłaszanych uzasadnionych opinii, intensywność dialogu politycznego itp.). Dodatkowo umieszczenie niekiedy w aktach wyższego rzędu przepisów prawnych o współpracy parlamentu z PE może nadawać tej części uprawnień parlamentu szczególny walor prawny. Zauważenie tych różnic może stanowić przyczynek do dalszej analizy na temat rozbudowy regulacji unijnych odnoszących się

${ }^{2}$ List J. Bizet, przewodniczącego Komisji Stałej do Spraw Europejskich w Senacie Republiki Francuskiej z 6 grudnia 2017 r. (LIX COSAC).

${ }_{3}^{3}$ Propozycja dotycząca zielonej kartki została sformułowana przez brytyjską Izbę Lordów w dokumencie Komisji do Spraw Unii Europejskiej na temat: Roli parlamentów narodowych w Unii Europejskiej, $<$ https://publications.parliament.uk/pa/ld201314/ldselect/ldeucom/151/151.pdf>, dostęp 28 VII 2018.

${ }^{4}$ Więcej na ten temat $\mathrm{w}$ Report on the implementation of the Treaty provisions concerning national parliaments (2016/2149(INI)), 28.03.2018, Committee on Constitutional Affairs of the European Parliament oraz w Working document on the implementation of the Treaty provisions concerning national parliaments, Committee on Constitutional Affairs of the European Parliament, 5.10.2017. 
do parlamentów narodowych i ich relacji z PE. Omówienie zasadniczej części pracy zostanie jednak poprzedzone historią kształtowania się podstaw prawnych relacji między parlamentami narodowymi a Parlamentem Europejskim ze szczególnym rozróżnieniem etapu sprzed i po wejściu w życie Traktatu z Lizbony. Liczba szczegółowych zagadnień związanych relacjami bilateralnymi Polski, Francji i Szwecji mogłaby z powodzeniem stać się przedmiotem wielu publikacji. Jednak należy podkreślić, że niniejszy artykuł nie wyczerpuje tematu, a stanowi zaledwie jego zarys. Ze względu na wcześniej wymienione cele $\mathrm{w}$ artykule zastosowano metodę historyczno-prawną. Opracowanie uwzględnia stan prawny na dzień 28 lipca $2018 \mathrm{r}$.

\section{HISTORIA REGULACJI}

Podstawy prawne współpracy między parlamentami narodowymi a Parlamentem Europejskim zostały uregulowane w art. 12 Traktatu o Unii Europejskiej [dalej: TUE], załączonym do niego Protokole $\mathrm{nr} 1 \mathrm{w}$ sprawie roli parlamentów narodowych w Unii Europejskiej $(\operatorname{art.} 2,3,9)$ oraz w Protokole $\mathrm{nr} 2 \mathrm{w}$ sprawie stosowania zasad pomocniczości i proporcjonalności (art. 6 i 7). Ponadto zasady tej relacji międzyinstytucjonalnej zostały również zawarte w regulaminie Parlamentu Europejskiego (art. 142, 143 i 144). W ramach tzw. funkcji europejskiej wzmocnieniu uległy m.in. dwie sfery aktywności: współpraca między parlamentami narodowymi oraz współpraca z Parlamentem Europejskim ${ }^{5}$.

\section{Ramy współpracy parlamentarnej przed Traktatem z Lizbony}

Pierwsze propozycje dotyczące wzmocnienia pozycji parlamentów narodowych na poziomie unijnym znalazły się $\mathrm{w}$ niewiążących dokumentach o charakterze politycznym, tj. w deklaracji nr 13, dotyczącej roli parlamentów krajowych w UE dołączonej do traktatu z Maastricht z 1992 r., która przewidywała zwiększenie wymiany informacji między parlamentami państw członkowskich a PE, oraz deklaracji nr $14 \mathrm{w}$ sprawie konferencji parlamentów zachęcającej do spotkań w ramach konferencji parlamentów, mającej udzielać konsultacji w sprawach dotyczących głównych kierunków rozwoju $\mathrm{UE}^{6}$. Pierwszym dokumentem o charakterze prawnym dotyczącym tej materii był Protokół nr 9 dołączony do traktatu z Amsterdamu w sprawie roli parlamentów narodowych państw członkowskich UE. Pierwsza część dokumentu dotyczyła udzielania informacji parlamentom narodowym. Druga odnosiła się do Konferencji Organów Wyspecjalizowanych w Sprawach Wspólnotowych [dalej: COSAC]. W ramach traktatu z Amsterdamu wprowadzono również Protokół nr $7 \mathrm{w}$ sprawie stosowania zasad pomocniczości i proporcjonalności. Protokoły te jednak nie zostały ze sobą powiązane, co ujawniło się w ich stosunku do traktatów założycielskich?

${ }^{5}$ A. Pudło, Funkcja europejska parlamentów państw czlonkowskich, „Przegląd Sejmowy” 2015, nr 1 , s. 7.

${ }^{6}$ E. Popławska, Rola parlamentów narodowych w świetle Traktatu z Lizbony, „Przegląd Sejmowy” 2010, nr 5, s. 160.

${ }^{7}$ C. Mik, Pozycja prawna parlamentów narodowych w Unii Europejskiej w świetle Traktatu Lizbony, „Ruch Prawniczy, Ekonomiczny i Socjologiczny” 2010, z. 2, s. 52. 
W dniach 14-15 grudnia 2001 r. na posiedzeniu Rady Europejskiej w Laeken przyjęto z kolei Deklarację w sprawie przyszłości Unii, dołączoną do traktatu z Nicei w 2001 r. W rezultacie Deklaracji z Laeken ustanowiono Konwent w Sprawie Przyszłości Europy. Dokument końcowy Czwartej Grupy Roboczej Konwentu stał się podstawą rozwiązań prawnych przewidzianych w Traktacie ustanawiającym Konstytucję dla Europy ${ }^{8}$, mimo że ten Traktat nie wszedł w życie, to stał się zbiorem postanowień włączonych w dużej mierze do Traktatu z Lizbony ${ }^{9}$. Dnia 3 lipca 2004 r., wraz z przyjęciem wytycznych w sprawie współpracy międzyparlamentarnej w Unii Europejskiej (wytyczne haskie) ${ }^{10}$, stwierdzono poszanowanie autonomii parlamentów i podkreślono, że głównym celem współpracy międzyparlamentarnej jest wymiana informacji oraz wzmocnienie kompetencji we wszystkich dziedzinach objętych zakresem prawa wspólnotowego. W wytycznych wspomniano również o różnych formatach współpracy międzyparlamentarnej.

$\mathrm{Na}$ przestrzeni lat efektywnym narzędziem międzyparlamentarnej współpracy administracyjnej oprócz Europejskiego Centrum Badań Parlamentarnych i Dokumentacji [dalej: ECPRD] ${ }^{11}$, utworzonego w 1977 r., stała się również platforma IPEX (funkcjonująca od 2006 r.). Celem tych projektów było usprawnienie systemów wymiany informacji, przekładające się na zaangażowanie parlamentów krajowych w sprawy Wspólnot Europejskich (później Unii Europejskiej).

\section{Współpraca parlamentarna po grudniu 2009 r.}

Do najważniejszych zmian — przełomowych po wejściu w życie Traktatu z Lizbony — należy przede wszystkim zaliczyć uwzględnienie parlamentów narodowych w Traktacie o Unii Europejskiej i dwóch załączonych protokołach. W zakresie współpracy parlamentów narodowych z PE po wejściu w życie tego aktu prawnego stworzono nowe elementy oddziaływania na decyzje unijne, także wzmocnieniu uległy istniejące już instrumenty: rozszerzono zakres dokumentów podlegających obowiązkowi wymiany informacji, przyznano prawo weta przy zmianie traktatów, prawo czuwania nad przestrzeganiem zasady pomocniczości, wprowadzono możliwość monitorowania przestrzeni wolności, bezpieczeństwa i sprawiedliwości, stworzono nowe formaty współpracy międzyparlamentarnej.

Niewątpliwą zmianą jakościową, jaka się dokonała po 2009 r., było oddziaływanie parlamentów krajowych na decyzje UE, jednocześnie nie nakładając na parlamenty

${ }^{8}$ A. Kurczuk, Rola parlamentów narodowych w świetle Traktatu Lizbońskiego, „Zeszyty Naukowe Akademii Podlaskiej w Siedlcach” 2010, nr 84, s. 127, <http://www.tstefaniuk.uph.edu.pl/zeszyty/archiwalne/ 84-2010_9.pdf>, dostęp 28 VII 2018.

9 C. Mik, Pozycja prawna parlamentów narodowych w Unii Europejskiej..., s. 52.

10 Przyjęte w Hadze 3 lipca 2004 r. przez Konferencję Przewodniczących Parlamentów UE, zmienione podczas konferencji w Lizbonie (19-21 czerwca 2008 r.).

11 Międzynarodowa sieć parlamentarnych wydziałów ds. badań i dokumentacji; jej członkami są: Parlament Europejski, Zgromadzenie Parlamentarne Rady Europy oraz izby parlamentów, których przewodniczący są członkami Europejskiej Konferencji Przewodniczących Parlamentów. Działalność ECPRD obejmuje organizację seminariów, przyjmowanie zapytań na określony temat oraz wydawanie publikacji. 
konkretnych zobowiązań ${ }^{12}$. Parlamenty krajowe uzyskały możliwość blokowania decyzji dzięki monitorowaniu zgodności unijnych aktów ustawodawczych z zasadą subsydiarności, przy zachowaniu określonych warunków formalnych niektórych propozycji uprawnionych podmiotów unijnych za pomocą tzw. żółtej lub pomarańczowej kartki w ramach mechanizmu wczesnego ostrzegania. Ponadto dzięki obowiązkom informacyjnym parlamenty narodowe dostały możliwość zapoznania się z projektami aktów prawnych $\mathrm{z}$ odpowiednim wyprzedzeniem ${ }^{13}$. Jedną z konsekwencji takiego ożywienia dialogu międzyparlamentarnego wewnątrz UE było również nadanie nowego impulsu istniejącym już formom współpracy parlamentarnej, takim jak Konferencje przewodniczących parlamentów UE (najwyższe rangą spotkanie parlamentarne), COSAC, wspólne spotkania parlamentarne, wspólne spotkania Komisji, Zgromadzenie Parlamentarne Unii dla Śródziemnomorza, ale i stworzenie nowych, np. Konferencja Międzyparlamentarna ds. Wspólnej Polityki Zagranicznej i Bezpieczeństwa oraz Wspólnej Polityki Bezpieczeństwa i Obrony, Konferencja Międzyparlamentarna ds. Stabilności, Koordynacji i Zarządzania Gospodarczego w Unii Europejskiej, Europejski Tydzień Parlamentarny czy Zgromadzenie Parlamentarne EURONEST. Kolejny obszar uprawnień przyznany zarówno PE, jak i parlamentom narodowym to ocena działalności Eurojustu ${ }^{14}$ (art. 85 Traktatu o funkcjonowaniu Unii Europejskiej, dalej: TfUE) i kontroli działań Europolu ${ }^{15}$ (art. 88 TfUE). Przejawem współpracy w tym zakresie jest funkcjonująca od października 2017 r. Grupa Wspólna ds. Kontroli Parlamentarnej Europolu. Wzajemne relacje obejmują również spotkania na szczeblu sekretarzy generalnych (szefów kancelarii) parlamentów narodowych, których celem jest przygotowanie Konferencji Przewodniczących Parlamentów. Do istniejących form współpracy należy również zaliczyć funkcjonowanie przedstawiciela parlamentów przy UE oraz udział deputowanych Parlamentu Europejskiego $\mathrm{w}$ pracach izb. Ponadto Traktat z Lizbony podniósł rangę parlamentów narodowych poprzez uwzględnienie ich stanowisk w procesie tworzenia acquis communautaire.

\section{DOŚWIADCZENIA WYBRANYCH PARLAMENTÓW NARODOWYCH W RELACJACH Z PARLAMENTEM EUROPEJSKIM}

Parlament Europejski jest instytucją odgrywającą kluczową rolę w relacjach międzyparlamentarnych w UE. Po pierwsze, jest on jednym z podmiotów funkcjonujących w ramach różnych form współpracy międzyparlamentarnej (często je inicjuje), a pod drugie, otrzymuje opinie wydawane przez parlamenty narodowe w sprawie

12 E. Popławska, Rola parlamentów narodowych..., s. 157.

13 Przepływ informacji dotyczących aktywności europejskiej parlamentów państw członkowskich z instytucjami unijnymi został usprawniony przez utworzenie w 2004 r. platformy IPEX (Interparliamentary EU Information Exchange).

${ }^{14}$ Europejska Jednostka Współpracy Sądowej (Eurojust), utworzona w 2002 r., jest agencją Unii Europejskiej. Jej celem jest wspieranie i wzmacnianie współpracy oraz koordynacji działań krajowych organów wymiaru sprawiedliwości w walce z przestępczością ponadgraniczną dotykającą kraje Unii Europejskiej.

15 Europejski Urząd Policji (Europol) to unijna agencja egzekwowania prawa, utworzona w 1999 r., której zadaniem jest zwiększanie poziomu bezpieczeństwa w Europie poprzez zapewnianie pomocy organom ścigania w państwach członkowskich UE. 
zgodności z zasadą subsydiarności ${ }^{16}$. Zakres tej współpracy jest również określony w szóstym tytule Regulaminu Parlamentu Europejskiego. Ten akt wewnętrzny zawiera regulacje dotyczące wymiany informacji, kontaktów, wzajemnych udogodnień (art. 142), udziału w COSAC (art. 143) oraz w innych konferencjach parlamentarnych (art. 144). Dodatkowo relacje między PE a parlamentami państw członkowskich były przedmiotem wielu rezolucji Parlamentu Europejskiego ${ }^{17}$ i opracowań.

Organami parlamentów wyspecjalizowanymi do kontaktu z instytucjami unijnymi są odpowiednie komisje, które w zależności od państwa mają większe lub mniejsze prerogatywy w zakresie współpracy z PE oraz z innymi organami Unii Europejskiej. Komisje te stanowią ważne ogniwo parlamentarnego procesu prawodawczego, kontrolnego i opiniotwórczego, a także tworzą system pomostów między legislacją unijną a krajowymi ciałami przedstawicielskimi ${ }^{18}$. Ramy współpracy z PE zostały określone m.in. w art. 9 Protokołu nr 1 w sprawie roli parlamentów narodowych w Unii Europejskiej oraz w wytycznych haskich. Strukturą w PE odpowiedzialną za kontakty z parlamentami narodowymi jest Dyrekcja ds. Stosunków z Parlamentami Narodowymi.

$\mathrm{Na}$ podstawie wspomnianych propozycji uwzględnione w regulacjach na poziomie unijnym parlamenty narodowe stworzyły własne mechanizmy wewnętrzne, będące realizacją norm traktatowych. Doświadczenia parlamentów Francji, Szwecji i Polski z PE różnią się między sobą intensywnością kontaktów oraz specyfiką regulacji własnych procedur wewnętrznych. Celem tego rozdziału jest ogólne omówienie rozwoju tych relacji, a także przedstawienie niektórych efektów tej współpracy po wejściu w życie przepisów Traktatu z Lizbony.

\section{Parlament Rzeczypospolitej Polskiej}

Początki współpracy polskiego parlamentu z Parlamentem Europejskim sięgają 1993 r., kiedy to utworzono Parlamentarną Komisję Wspólną RP i UE (PKWRPiUE) ${ }^{19}$. Następnie, po podpisaniu 16 kwietnia 2003 r. Traktatu akcesyjnego do wejścia do Unii Europejskiej, 54 polskich parlamentarzystów, delegowanych zarówno z Sejmu, jak i z Senatu, uczestniczyło w pracach Parlamentu Europejskiego w charakterze obserwatorów. Po przystąpieniu Polski do Unii Europejskiej w 2004 r. istotnym forum współpracy z PE stała się Konferencja Organów Wyspecjalizowanych w Sprawach Wspólnotowych

${ }^{16}$ M. Remáč, Working with national parliaments on EU affairs, European Parliamentary Research Service, PE 603.271 — October 2017, <http://www.europarl.europa.eu/thinktank/en/document.html?refe rence=EPRS_STU \%282017\%29603271>, dostęp 28 VII 2018.

17 Do najważniejszych należy zaliczyć m.in. rezolucję z 7 maja 2009 r. w sprawie rozwoju stosunków między Parlamentem Europejskim a parlamentami narodowymi w kontekście Traktatu z Lizbony, rezolucję z 16 kwietnia 2014 r. w sprawie stosunków między Parlamentem Europejskim a parlamentami narodowymi, rezolucję z 19 kwietnia 2018 r. w sprawie stosowania postanowień Traktatu dotyczących parlamentów narodowych.

18 M. Serowaniec, Parlamentarne Komisje do Spraw Europejskich, Warszawa 2016, s. 8.

19 Vide szerzej J. Borkowski, Role of the Poland-EU Joint Parliamentary Committee in Poland's Preparations for European Union Membership, <http://www.ce.uw.edu.pl/pliki/pw/y3-1999_Borkowski.pdf>, dostęp 28 VII 2018. 
i Europejskich Parlamentów Unii Europejskiej $(\mathrm{COSAC})^{20}$. Dzięki temu parlament uzyskał możliwość dostępu do informacji o zamierzeniach PE oraz kierowania sugestii w sprawie kierunku jego prac. Sejm 11 marca 2004 r. uchwalił ustawę będącą podstawą współpracy naczelnych organów państwowych z organami Unii Europejskiej. Obecnie ta materia jest regulowana ustawą kooperacyjną ${ }^{21} \mathrm{z} 8$ października 2010 r., o tym samym tytule, co poprzednia. Ten akt prawny normalizuje stosunki między Sejmem, Senatem i Radą Ministrów a organami Unii Europejskiej, przyznając prawo do otrzymywania m.in. projektów umów międzynarodowych, dokumentów UE podlegających konsultacjom z państwami członkowskimi (białe i zielone księgi), komunikaty Komisji Europejskiej, planów prac Rady UE czy rocznych planów legislacyjnych Komisji Europejskiej. Ponadto sferę działalności organów obu izb wyspecjalizowanych w sprawach europejskich reguluje regulamin Sejmu ${ }^{22}$ i regulamin Senatu ${ }^{23}$. Zgodnie z ich przepisami Komisja do spraw Europejskich (Sejm) ${ }^{24}$ oraz Komisja Spraw Zagranicznych i Unii Europejskiej (Senat) ${ }^{25}$ mogą uchwalać opinie o projekcie aktu prawnego UE, opinie o stanowiskach Rzeczypospolitej Polskiej zajmowanych w trakcie procedur stanowienia prawa Unii, a także opinie w sprawie informacji Rady Ministrów o stanowisku Rzeczypospolitej Polskiej, jakie Rada Ministrów ma zamiar zająć podczas rozpatrywania projektu w Radzie (art. 148c regulaminu Sejmu i art. 75b regulaminu Senatu). Możliwość procedowania nad projektami unijnych aktów prawnych oraz stanowisk Rady Ministrów dała władzy ustawodawczej wpływ na proces rozwoju $\mathrm{UE}^{26}$. Zgodnie z art. 7 ust. 4 ustawy kooperacyjnej komisje ds. europejskich mogą ponadto wyrażać opinię o projekcie aktu ustawodawczego, a także o projekcie aktu nieustawodawczego (art. 8 ust. 2). Inne kompetencje dotyczą możliwości wyrażenia opinii na temat stanowisk zajmowanych przez Radę Ministrów w trakcie procedur stanowienia prawa UE (art. 10 ust. 2) albo opinię o stanowisku, które Rada Ministrów zamierza zająć podczas rozpatrywania tego aktu na posiedzeniu Rady UE (art. 11 ust. 1 i art. 12 ust. 1) lub Rady Europejskiej (art. 12

${ }^{20}$ Obecna nazwa: Konferencja Komisji do Spraw Unijnych Parlamentów Unii Europejskiej (COSAC), [w:] Leksykon Konferencji Komisji do Spraw Unijnych Parlamentów Unii Europejskiej (COSAC), <http:// oide.sejm.gov.pl/oide/index.php?option=com_content\&view $=$ article\&id=14727\&Itemid=776>, dostęp 28 VII 2018.

${ }^{21}$ Ustawa z dnia 8 października 2010 r. o współpracy Rady Ministrów z Sejmem i Senatem w sprawach związanych z członkostwem Rzeczypospolitej Polskiej w Unii Europejskiej (Dz.U. z 2010 r. nr 213, poz. 1395) zastąpiła wcześniej obowiązującą ustawę z dnia 11 marca 2004 r. o współpracy Rady Ministrów z Sejmem i Senatem w sprawach związanych z członkostwem Rzeczypospolitej Polskiej w Unii Europejskiej (Dz.U. z 2004 r. nr 52, poz. 515).

${ }_{22}$ Rozdział 13a: art. 148a-148e uchwały Sejmu Rzeczypospolitej Polskiej z dnia 30 lipca 1992 r. — Regulamin Sejmu Rzeczypospolitej Polskiej (M.P. z 2012 r. poz. 32 z późń. zm.).

${ }^{23}$ Rozdział 8a: art. 75a-75g uchwały Senatu Rzeczypospolitej Polskiej z dnia 23 listopada 1990 r. Regulamin Senatu (M.P. z 2017 r. poz. 827 z późn. zm.).

${ }^{24}$ Wcześniej Komisja Integracji Europejskiej (1993-2001, II i III kadencja Sejmu), Komisja do Spraw Układu Europejskiego (1992-1993, I kadencja Sejmu).

${ }^{25}$ Wcześniej Komisja Spraw Unii Europejskiej (2004-2011, V-VII kadencja Senatu), Komisja Spraw Zagranicznych i Międzynarodowych Stosunków Gospodarczych (listopad-grudzień 1997 r., IV kadencja Senatu) oraz Komisja Spraw Zagranicznych i Integracji Europejskiej (1997-2001).

${ }^{26}$ M. Serowaniec, Parlamentarne Komisje..., s. 230. 
ust. 2). Należy podkreślić, że opinie Komisji do Spraw Unii Europejskiej nie mają charakteru bezwzględnie wiążącego, a raczej pomocniczy ${ }^{27}$.

Postanowienia ustawy kooperacyjnej z 2010 r. różnicują pozycję Sejmu i Senatu, w tym ich komisji w odniesieniu do spraw UE. Różnica ta jest widoczna chociażby w tym, że komisja senacka nie ma możliwości wyrażania opinii w sprawie kandydatów państwa na najważniejsze stanowiska w instytucjach UE. Jednak obu izbom przyznano taki sam zakres informacji przekazywanych przez Radę Ministrów. Ze względu na zakres uprawnień pozycja komisji sejmowej jest mocniejsza od senackiej. Ważnym elementem aktywności europejskiej polskich izb parlamentarnych jest badanie unijnych aktów ustawodawczych pod względem zgodności z zasadą pomocniczości. Procedura jest uruchamiana od momentu wpływu do sekretariatu Komisji do Spraw Unii Europejskiej listu przewodniego (lettre de saisine) zawierającego informację o przekazaniu wszystkich wersji językowych parlamentom państw członkowskich i określającego procedurę oraz wyznaczającego termin. Od tego momentu zaczyna biec termin ośmiu tygodni na ewentualne przekazanie przez parlament państwa członkowskiego uzasadnionej opinii.

Wymiana dokumentów oraz cykliczne spotkania w ramach różnych form współpracy międzyparlamentarnej nie są jedynymi narzędziami kształtowania relacji między Sejmem i Senatem a Parlamentem Europejskim. Polscy deputowani do Parlamentu Europejskiego (51 posłów), poprzez uczestniczenie w różnych koalicjach i działalności organów Parlamentu Europejskiego, mają bezpośredni wpływ na prace Parlamentu. Warto również zwrócić uwagę na rolę przedstawicieli obu izb przy UE, których zadaniem jest zapewnienie szczegółowej bieżącej informacji o wydarzeniach istniejących $\mathrm{w}$ instytucjach unijnych i innych parlamentach państw członkowskich oraz o przebiegu wspólnotowego procesu legislacyjnego, w szczególności w odniesieniu do projektów aktów prawa opiniowanych przez sejmową Komisję do Spraw Unii Europejskiej i senacką Komisję Spraw Zagranicznych i Unii Europejskiej.

\section{Riksdag Królestwa Szwecji}

Wraz z przystąpieniem Szwecji do Unii Europejskiej w 1995 r. Riksdag uzyskał możliwość wywierania wpływu na prace prowadzone w Unii oraz podejmowane przez nią decyzje. Prace parlamentu zostały zorganizowane w ten sposób, aby mogły oddziaływać na działania rządu w ramach UE. Współpraca z rządem jest prowadzona w różnej formie na posiedzeniach plenarnych, w ramach prac komisji Riksdagu a także w Komisji Doradczej do spraw Unii Europejskiej. Parlament szwedzki należy do tej grupy państw, które mają duży wpływ na pracę państwa w Unii Europejskiejej. Od 1995 r. sposób zajmowania się sprawami unijnymi przez Riksdag zmienił się kilkanaście razy ${ }^{29}$, w tym

27 Ibidem.

${ }_{28}$ Zapis spotkania Komisji Integracji Europejskiej z przewodniczącym Komisji Doradczej do spraw Unii Europejskiej Riksdagu, 17 styczeń 2001 r., Biuletyn Komisji Sejmowych 3719/III, Komisja Integracji Europejskiej, nr 83.

${ }_{29}$ The Riksdag and the European Union, s. 6, <http://www.ipex.eu/IPEXL-WEB/parliaments/insti tution/serik>, dostęp 28 VII 2018. 
m.in. w 2007 r. wprowadzono zmiany umożliwiające Izbie wkroczenie we wczesnym stadium w proces podejmowania decyzji i które wiązały się z nowymi zadaniami komisji. Komisje uzyskały w ten sposób możliwość podejmowania dyskusji z rządem o sprawach europejskich, które znajdowały się w zakresie ich kompetencji. Komisje otrzymały również prawa badania inicjatyw unijnych instytucji. Po wejściu w życie Traktatu z Lizbony wprowadzono do Riksdag Akt postanowienia dotyczący badania przestrzegania zasady subsydiarności i udziału w zmianie traktatów unijnych ${ }^{30}$.

W parlamencie szwedzkim działa obecnie 15 komisji, które mają za zadanie monitorowanie spraw związanych z Unią Europejską. W praktyce komisje te badają propozycje unijne i sporządzają sprawozdanie, a dopiero wówczas zajmuje się tym rząd. Sekretariaty komisji dzięki specjalnej jednostce koordynacyjnej UE otrzymują wsparcie we wszelkich kwestiach proceduralnych i instytucjonalnych $\mathrm{UE}^{31}$. Specjalnym organem jest wspomniana Komisja Doradcza do spraw Unii Europejskiej funkcjonująca przy Riksdagu, która przedstawia swoją opinię Radzie Ministrów przed spotkaniami Rady Unii Europejskiej ${ }^{32}$. Komisja ds. Europejskich składa się z nieparzystej liczby członków, lecz z nie mniej niż 15, wybieranych ze wszystkich partii politycznych proporcjonalnie do układu sił w Izbie (7.4. Riksdag Act). Wszelka aktywność instytucji unijnych jest monitorowana przez rząd, który jest zobligowany do konsultacji z komisjami parlamentarnymi we wszelkich kwestiach dotyczących spraw europejskich. Rząd - w celu wzmocnienia swojego mandatu dla reprezentowania swojego kraju — ma również obowiązek konsultowania z Komisją ds. Europejskich wszelkich kwestii przedłożonych na agendzie Rady Unii Europejskiej (7.14. Riksdag Act). Obowiązki informacyjne rządu w tym zakresie są wypełniane zarówno podczas prac komisji branżowych, Komisji ds. Europejskich, a także in pleno na posiedzeniu całej Izby ${ }^{33}$. Debaty w sprawach europejskich odbywają się w sali posiedzeń Riksdagu. Część uprawnień związanych z tworzeniem prawa została przekazana Parlamentowi Europejskiemu. Zasady współpracy między tymi trzema ośrodkami zostały uregulowane w Instrument of Government ${ }^{34}$ oraz w Riksdag Act ${ }^{35}$. Każdego roku odbywa się debata lub przedstawiany jest raport w sprawie polityki europejskiej, która jest monitorowana przez Komisję do spraw Konstytucyjnych $^{36}$.

Zgodnie z Riksdag Act parlament przeprowadza kontrolę subsydiarności wszystkich projektów aktów legislacyjnych w obszarach należących zarówno do kompetencji

${ }^{30}$ The Riksdag and the European Union, s. 6 <http://www.ipex.eu/IPEXL-WEB/parliaments/insti tution/serik>, dostęp 28 VII 2018.

31 Wystąpienie sekretarza generalnego Riksdagu Claesa Mårtenssona podczas spotkania Sekretarzy Generalnych w Wilnie, 26-27 stycznia 2014 r.

32 The Riksdag and the European Union, < http://www.ipex.eu/IPEXL-WEB/parliaments/institu tion/serik>, dostęp 28 VII 2018.

33 Strona internetowa Riksdagu <http://www.cosac.eu/subs-sweden>, dostęp 28 VII 2018.

34 Strona internetowa Riksdagu < http://www.riksdagen.se/globalassets/07.-dokument--lagar/the-con stitution-of-sweden>, dostęp 28 VII 2018.

35 Ibidem.

${ }^{36}$ Na podstawie informacji ze strony internetowej Riksdagu $<$ http://www.riksdagen.se/en/committees/ the-parliamentary-committees-at-work>, dostęp 28 VII 2018. 
członków UE, jak i PE. Zasada subsydiarności zakłada, aby decyzje podejmowane na poziomie politycznym były zgodne $\mathrm{z}$ wolą wyborców ${ }^{37}$. Podobnie jak w przypadku innych parlamentów państw UE badanie propozycji legislacyjnych stanowi jeden z głównych obszarów aktywności. W odniesieniu do parlamentu szwedzkiego projekt jest przekazywany komisji, która zajmuje się zagadnieniami przedstawionymi w akcie. W razie wątpliwości właściwa komisja przeprowadza kontrolę subsydiarności. W wypadku stwierdzenia naruszenia przedstawia całej Izbie oświadczenie z propozycją uzasadnionej opinii skierowanej do przewodniczącego PE, Rady i Komisji. Na wniosek co najmniej pięciu członków Komisji o naruszaniu w projekcie legislacyjnym zasady subsydiarności sporządza się oświadczenie. Następnie projekt jest zatwierdzany przez Riksdag (10.3 Riksdag Act).

Stanowisko formułowane przez Komisję Doradczą jest uwzględniane przy opracowywaniu mandatu negocjacyjnego przed posiedzeniami Rady, a także stanowi ono forum współpracy i konsultacji parlamentarzystów z członkami rządów w sprawach związanych z integracją europejską ${ }^{38}$. Riksdag należy do parlamentów państw Unii Europejskiej, które zgłaszają najwięcej uzasadnionych opinii i wspierają różne formy współpracy, jak np. IPEX, Europol ${ }^{39}$. Czynnikiem wpływającym na taki wynik jest to, że każda komisja ma możliwość poddania swoich ekspertyz przeglądowi pod względem subsydiarności.

Do końca 2017 r. Riksdag przyjął 59 uzasadnionych opinii. Szwecja jako państwo członkowskie ma również możliwość bezpośredniego wpływania na pracę Parlamentu Europejskiego przez swoich 20 eurodeputowanych. Ponadto funkcjonujący od 2005 r. stały przedstawiciel Riksdagu w instytucjach europejskich zapewnia wraz z Sekretariatem Koordynacyjnym EU informacje o wydarzeniach w instytucjach unijnych oraz w innych parlamentach państw członkowskich ${ }^{40}$.

\section{Parlament Republiki Francuskiej}

Republika Francuska jest państwem najdłużej związanym z procesem integracji europejskiej (od 1957 r.), tym samym również relacje francuskiego parlamentu z Parlamentem Europejskim sięgają początków istnienia tej instytucji. We Francji delegacje parlamentarne dla Wspólnot Europejskich zostały utworzone wraz z przyjęciem ustawy 6 lipca 1979 r. ${ }^{41}$ Następnie ustawą z 10 czerwca 1994 r. (Loi Pandraud

${ }^{37}$ The Riksdag and the European Union..., dostęp 28 VII 2018.

${ }_{38}^{38}$ M. Serowaniec, Parlamentarne Komisje..., s. 108-109.

${ }^{39}$ Wystąpienie przewodniczącego Riksdagu U. Ahlina 24 maja 2016 r. w Luksemburgu na temat „Roli parlamentów narodowych i współpracy międzyparlamentarnej podczas Konferencji Przewodniczących Parlamentów Europejskich", <http://www.ipex.eu/IPEXLWEB/euspeakers/getspeakers.do?id=082dbcc54d8d4e af0>, dostęp 28 VII 2018.

${ }^{40}$ The Riksdag and the European Union..., dostęp 28 VII 2018.

${ }^{41}$ Loi n $^{\circ} 79-654$ du 6 juillet 1979 modifiant l'ordonnance $n^{\circ}$ 58-1000 du 17 novembre 1958 relative au fonctionnement des assemblées parlementaires en veu de la creation des delegations parlementaires pour les communautés européennes, <http://www.assemblee-nationale.fr/europe/loi_juillet.asp >, dostęp 28 VII 2018. 
$\mathrm{n}^{\circ}$ 94-476 du 10 juin 1994) ${ }^{42}$ wprowadzono zobowiązanie rządu do przekazywania delegaturze „wszelkich niezbędnych dokumentów sporządzonych przez różne instytucje Unii Europejskiej”. Z kolei ustawą konstytucyjną z 23 lipca 2008 r. ustanowiono w obu izbach parlamentu Komisję do Spraw Europejskich, która przejęła delegatury. W trakcie przeglądu regulaminu izby niższej (Règlement de l'Assemblée nationale) z 27 maja 2009 r. zwiększono liczbę członków z 36 do 48 i uproszczono procedury przyjmowania rezolucji europejskich ${ }^{43}$. Regulacje dotyczące nowych funkcji parlamentu (po 2009 r.) zostały zawarte zarówno w Konstytucji Republiki Francuskiej (art. 88-6 i art. 88-7), jak i w aktach niższego rzędu, tzn. Règlement du Sénat ${ }^{44}$ oraz Règlement de l'Assemblée nationale ${ }^{45}$.

Warto zaznaczyć, że francuska ustawa zasadnicza w 15. rozdziale bezpośrednio odwołuje się do Traktatu z Lizbony, wskazując explicite uprawnienia obu izb parlamentu, m.in. w zakresie badania zasady subsydiarności oraz wyrażenia sprzeciwu w kwestii zmiany norm dotyczących stanowienia aktów UE na podstawie uproszczonej nowelizacji traktatów lub współpracy sądowej w sprawach cywilnych. Zgodnie z nimi to rezolucje dotyczące projektów lub wniosków mogą być przyjmowane zarówno na sesjach, jak i poza nimi według regulacji wewnętrznych każdej z izb (art. 88-4). Wszelkie akty zatwierdzające ratyfikację traktatu w sprawie przystąpienia państwa do Unii Europejskiej są przedkładane w drodze referendum prezydentowi Republiki (art. 88-5). Każda izba parlamentu francuskiego może zaskarżyć do Trybunału Sprawiedliwości UE europejski akt prawny, który narusza zasadę subsydiarności. Na wniosek 60 deputowanych lub 60 senatorów zaskarżenie jest dokonywane z mocy prawa (art. 88-6). Uprawnienia obu izb parlamentu w zakresie badania zasady pomocniczości, jak i wnoszenia skargi do Trybunału Sprawiedliwości zostały zrównane.

Spośród wymienionych państw Francja posiada najliczniejszą 74-osobową reprezentację w Parlamencie Europejskim i podobnie jak polski parlament ma dwóch przedstawicieli (po każdym z izby) przy UE.

\section{PODSUMOWANIE}

Współpraca parlamentów narodowych z Parlamentem Europejskim w zakresie tworzenia prawa jest procesem złożonym i wieloetapowym. Niewątpliwie Traktat z Lizbony ożywił międzynarodowy dialog parlamentarny przyznając większy wpływ na proces decyzyjny w Unii Europejskiej i podnosząc rangę parlamentów państw członkowskich po przez zamieszczenie norm prawnych o ich roli w swojej treści. Akt ten dał również

${ }^{42}$ Les relations internationales, $<$ http://www.assemblee-nationale.fr/qui/relations-inter.pdf $>$, dostęp 28 VII 2018.

${ }^{43}$ Na podstawie informacji ze strony internetowej Zgromadzenia Narodowego Republiki Francuskiej, $<$ http://www2.assemblee-nationale.fr/15/autres-commissions/commission-des-affaires-europeennes/liens>, dostęp 28 VII 2018.

${ }_{44}$ Art. 73 regulaminu Senatu odnosi się do kompetencji Komisji Spraw Europejskich, <http://www. senat.fr/reglement/reglement_mono>, dostęp 28 VII 2018.

${ }^{45}$ Art. 151-1 - 151-12 regulaminu Zgromadzenia Narodowego odnoszą się do kompetencji Komisji Spraw Europejskich, <http://www.assemblee-nationale.fr/connaissance/reglement>, dostęp 28 VII 2018. 
impuls do dalszych zmian na tym polu, a prowadzone debaty w ramach różnych form współpracy parlamentarnych na ten temat są tego potwierdzeniem.

Zapewnienie dywersyfikacji instrumentów do współtworzenia polityki europejskiej — również tych na poziomie parlamentarnym — jest warunkiem koniecznym do dalszego wzmacniania Unii Europejskiej i pozycji państw członków. Usprawnianie współpracy dwustronnej między parlamentami państw członkowskich a PE jest korzystne dla obu stron: parlamenty państw członkowskich zyskują większy wpływ na proces decyzyjny UE i następuje umocnienie legitymacji demokratycznej Parlamentu Europejskiego. Ewolucja relacji parlamentów Polski, Francji i Szwecji z Parlamentem Europejskim pokazuje różnice w podejściu do sposobu regulacji wewnętrznych tej kwestii, odmiennym sposobie procedowania nad aktami unijnymi, rozbieżności w przyznawaniu prerogatyw poszczególnym organom izb parlamentarnych oraz zdolności wywierania wpływu na rząd w sprawach unijnych. Regulacje relacji międzyparlamentarnych mają również bezpośrednie odzwierciedlenie w danych statystycznych dotyczących liczby zgłaszanych uzasadnionych opinii (największą aktywność, jaką przyznał parlamentom narodowym Traktat z Lizbony w sferze mechanizmu wczesnego ostrzegania, przejawiał szwedzki Riksdag). Zebrane informacje na temat stosunków wybranych parlamentów państw członkowskich UE z Parlamentem Europejskim skłaniają do refleksji na temat roli parlamentów narodowych w procesie decyzyjnym Unii Europejskiej i ewentualnych możliwościach jej zwiększania.

\section{BIBLIOGRAFIA}

ŹRÓDŁA

P o l s k a

Ustawa z dnia 8 października 2010 r. o współpracy Rady Ministrów z Sejmem i Senatem w sprawach związanych z członkostwem Rzeczypospolitej Polskiej w Unii Europejskiej, Dz.U. z 2010 r. nr 213, poz. 1395.

Uchwała Sejmu Rzeczypospolitej Polskiej z dnia 30 lipca 1992 r. — Regulamin Sejmu Rzeczypospolitej Polskiej, tekst jedn. M.P. z 2012 r. poz. 32 z późń. zm.).

Uchwała Senatu Rzeczypospolitej Polskiej z dnia 23 listopada 1990 r. — Regulamin Senatu, M.P. z 2017 r. poz. 827 z późn. zm.

$\mathrm{S} z \mathrm{w}$ e c j a

The Constitution of Sweden. The Fundamental Law and the Riksdag Act, <http://www.riksda gen.se/globalassets/07.-dokument--lagar/the-constitution-of-sweden-160628.pdf>.

Fra n c j a

Constitution de la République française. Constitution du 4 octobre 1958 (Version mise à jour en janvier 2015), <http://www.assemblee-nationale.fr/connaissance/constitution.asp $>$.

Le Règlement du senat et instruction generale du bureau (mise à jour en 16 janvier 2018), $<$ http://www.senat.fr/reglement/reglement_mono.html\#toc0>.

Le Règlement de l'Assemblée nationale (mise à jour en juin 2018), <http://www.assemblee-na tionale.fr/connaissance/reglement.pdf $>$. 
Loi $n^{\circ} 79-654$ du 6 juillet 1979 modifiant l'ordonnance no 58-1000 du 17 novembre 1958 relative au fonctionnement des assemblées parlementaires en veu de la creation des delegations parlementaires pour les communautés européennes, <http://www.assemblee-nationale.fr/ europe/loi_juillet.asp $>$.

Un i a E ropej s k a

Traktat o Unii Europejskiej, wersja skonsolidowana 2016, Dz. Urz. UE 2016 C 202. Traktat o funkcjonowaniu Unii Europejskiej 2016, Dz. Urz. UE 2016 C 202, s.1.

Regulamin Parlamentu Europejskiego, VIII kadencja, lipiec 2018, <http://www.europarl.europa. eu/sides/getDoc.do?pubRef=//EP//TEXT+RULESEP+20180731+TOC+DOC+XML+V0// PL\&language $=\mathrm{PL}>$.

\section{PIŚMIENNICTWO}

Borkowski J., Role of the Poland-EU Joint Parliamentary Committee in Poland's Preparations for European Union Membership, <http://www.ce.uw.edu.pl/pliki/pw/y3-1999_Borkowski.pdf>.

Kurczuk A., Rola parlamentów narodowych $w$ świetle Traktatu Lizbońskiego, „Zeszyty Naukowe Akademii Podlaskiej w Siedlcach" 2010, nr 84.

Mik C., Pozycja prawna parlamentów narodowych w Unii Europejskiej w świetle Traktatu Lizbony, „Ruch Prawniczy, Ekonomiczny i Socjologiczny”, 2010, z. 2.

Popławska E., Rola parlamentów narodowych $w$ świetle Traktatu z Lizbony, „Przegląd Sejmowy" 2010, nr 5.

Pudło A., Funkcja europejska parlamentów państw członkowskich, „Przegląd Sejmowy” 2015, nr 1.

Remáč M., Working with national parliaments on EU affairs, European Parliamentary Research Service, PE 603.271-October 2017, <http://www.europarl.europa.eu/thinktank/en/document. html?reference=EPRS_STU\%282017\%29603271>.

Serowaniec M., Parlamentarne Komisje do Spraw Europejskich, Wydawnictwo Sejmowe, Warszawa 2016.

STRONY INTERNETOWE

Strona internetowa COSAC (Konferencja Komisji do Spraw Unijnych Parlamentów Unii Europejskiej), $<$ http://www.cosac.eu/subs-sweden>.

Strona internetowa IPEX (Międzyparlamentarna Wymiana Informacji w Sprawach UE), <http:// www.ipex.eu/IPEXL-WEB/parliaments/institution/serik.do>, The Riksdag and the European Union.

Strona internetowa Parlamentu Europejskiego, $<$ http://www.europarl.europa.eu/calendar/ca lendar?APP=PDF\&TYPE=PV2\&FILE=19970612EN.pdf\&LANGUE=EN $>$, Resolution on the relations between the European Parliament and national parliaments, T4-0319/1997, 22.02.1997.

Strona internetowa Parlamentu Królestwa Szwecji, <http:/www.riksdagen.se/en/ committees/ the-parliamentary-committees-at-work $>$.

Strona internetowa Parlamentu Zjednoczonego Królestwa Wielkiej Brytanii i Irlandii Północnej Rola parlamentów narodowych w Unii Europejskiej, <https://publications.parliament.uk/ pa/ld201314/ldselect/ldeucom/151/151.pdf>.

Strona internetowa Zgromadzenia Narodowego Republiki Francji, $<$ http://www2.assemblee-na tionale.fr/15/autres-commissions/commission-des-affaires-europeennes/liens/presenta tion-de-la-commission-des-affaires-europeennes>. 